\title{
Thermotherapy and Storage Temperature Manipulations Limit the Production of Reactive Oxygen Species in Stored Pedunculate Oak Acorns
}

\author{
Ewa Marzena Kalemba *(D, Mikołaj Krzysztof Wawrzyniak (D), Jan Suszka (D) and Paweł Chmielarz *(D) \\ Institute of Dendrology Polish Academy of Sciences, Parkowa 5, 62-035 Kórnik, Poland; \\ mikwaw@man.poznan.pl (M.K.W.); jsuszka@man.poznan.pl (J.S.) \\ * Correspondence: kalemba@man.poznan.pl (E.M.K.); pach@man.poznan.pl (P.C.); Tel.: +48-618-170-033 (E.M.K.)
}

check for

updates

Citation: Kalemba, E.M.;

Wawrzyniak, M.K.; Suszka, J.;

Chmielarz, P. Thermotherapy and

Storage Temperature Manipulations

Limit the Production of Reactive

Oxygen Species in Stored

Pedunculate Oak Acorns. Forests

2021, 12, 1338. https://doi.org/

$10.3390 /$ f12101338

Academic Editor: Adele Muscolo

Received: 13 September 2021

Accepted: 27 September 2021

Published: 30 September 2021

Publisher's Note: MDPI stays neutral with regard to jurisdictional claims in published maps and institutional affiliations.
Abstract: For many species, seed storage protocols are still being improved to provide viable seeds of the highest quality. Seed storage is extremely problematic for short-lived seeds categorized as recalcitrant, including pedunculate oak (Quercus robur L.), for which the optimal seed storage protocol involves a temperature of $-3{ }^{\circ} \mathrm{C}$ and $40 \%$ acorn moisture content recommendations. The sensitivity of pedunculated oak seeds to temperature manipulations under preparation for long-term storage has been poorly investigated, particularly in terms of the production of reactive oxygen species (ROS), which are assumed to be determinants of seed longevity. Thermotherapy, the pathogen elimination procedure, did not increase the level of three types of ROS: hydrogen peroxide $\left(\mathrm{H}_{2} \mathrm{O}_{2}\right)$, superoxide anion radical and hydroxyl radical $(\bullet \mathrm{OH})$. The temporal heat stress of thermotherapy resulted in slightly reduced levels of $\mathrm{H}_{2} \mathrm{O}_{2}$, indicating activation of the antioxidant systems in acorn preparation for storage. The effect of constant storage temperatures $\left(-3,-5,-7^{\circ} \mathrm{C}\right)$ and their combinations $\left(-3 \rightarrow-5{ }^{\circ} \mathrm{C}\right.$ or $\left.-3 \rightarrow-5 \rightarrow-7^{\circ} \mathrm{C}\right)$ on ROS levels and seed viability was investigated in three provenances. The highest ROS levels were detected in acorns stored at $-7^{\circ} \mathrm{C}$, whereas three-step cold acclimation was beneficial for reducing ROS levels. Interestingly, the levels of $\mathrm{H}_{2} \mathrm{O}_{2}$ were not affected by temperature in thermotherapized acorns. In contrast, decreasing storage temperature caused a linear increase in $\bullet \mathrm{OH}$ levels in all provenances. The effect of heat stress and cold stress on ROS levels in relation to long-term seed storage of pedunculate oak is discussed here in relation to the seed viability evidenced via germination rates, seedling emergence and electrolyte leakage. Thermotherapy and cold acclimation of acorns can improve their viability after storage by decreasing ROS levels.

Keywords: cold acclimation; hydrogen peroxide; hydroxyl radical; Quercus robur; seed germination; seed viability; seedling emergence; superoxide anion radical; thermotolerance

\section{Introduction}

Temperature is an abiotic factor limiting the types of organisms that can exist in a certain ecosystem. Living organisms are sensitive to thermal extremes [1]. In identifying thresholds for heat stress, the heat tolerance and thermal adaptation of a species must be considered [2]. The response of an organism to changing temperature conditions is termed temperature sensitivity, which affects organism fitness by promoting growth and development or inducing mortality [3]. Acclimation is a set of physiological changes that reduce or enhance tolerance to experimentally induced stressful factors, specifically climatic factors [4]. A rise in temperature, usually $10-15^{\circ} \mathrm{C}$ above ambient temperature, is considered heat shock or heat stress [5], whereas lower temperatures result in cold stress. Below $20^{\circ} \mathrm{C}$ and below $0{ }^{\circ} \mathrm{C}$ induces chilling and freezing injury, respectively [6,7].

Postharvest technology based on physical treatments, including heat treatment, is aimed at the distribution of high-quality and nutritional food [8]. Importantly, hot water treatment eliminates seed pathogens. Heat treatment was first used in 1882 to disinfest 
seed potatoes from late blight [9]. Fungal development is the major factor limiting the long-term storage of recalcitrant seeds. In recent decades, Ciboria batschiana was the major fungal pathogen [10], particularly for moist acorn storage [11]. Therefore, thermotherapy by hot water $\left(2.5 \mathrm{~h}\right.$ at $\left.41^{\circ} \mathrm{C}\right)$ was recommended to limit C. batschiana prior to oak seed storage [12,13] and was successfully applied in pedunculate oak acorns [14,15]. More precisely, the above thermotherapy efficiently eradicated a part of the mycobiota, mainly Penicillium spp., in pedunculate oak acorns, but storage temperatures and storage duration still determine the development of fast-colonizing fungi and acorn deterioration [16].

It is still unknown whether a temperature of $41^{\circ} \mathrm{C}$ is a stress factor, and thermotherapy eventually elevates the production of reactive oxygen species (ROS). Temperature stress stimulates ROS generation and, at the same time, stimulates ROS defense and temperature defense pathways [17]. ROS regulatory systems govern defense and acclimatory responses under stress combinations [18]. How heat acclimation and defense mechanisms are joined via ROS under heat stress, pathogen infection and their combinations remains undiscovered.

Combined temperature treatments are more beneficial to sustain plant fruit quality than a single treatment at a constant temperature. Loayza et al. [19] demonstrated in tomato a synergistic positive effect of combined temperature treatments on fruit ripening and an increase in antioxidant levels were reported. More precisely, enhanced levels and activities were detected for substances scavenging ROS.

Seed longevity is a polygenic trait that requires the coordination of many biological processes shaping the stability of seeds in the soil and their ex situ storage time [20]. Recently, a genome-wide association study revealed that seed longevity is determined via the expression of genes involved in ROS metabolism and detoxification and in the development of the seed coat [21]. The oxidative stress theory of aging via the production of ROS was proposed by Harman [22]. While ROS play a signaling role in the regulation of seed germination and dormancy [23], ROS overproduction contributes to seed deterioration and aging [24].

Variations in seed storage characteristics are reflected in seed categories: from desiccation-tolerant orthodox seeds to desiccation-sensitive recalcitrant seeds and between intermediate seeds [25], while the storage of recalcitrant seeds is very limited [26]. Optimized seed storage temperature in combination with seed moisture content affects ROS levels and seed longevity. More precisely, storage duration-dependent oxidative processes were detected in orthodox (desiccation tolerant) seeds of wild fruit trees [27] and intermediate poplar seeds [28], clearly demonstrating ROS production in response to a certain storage temperature condition. In this context, recalcitrant seeds are assumed to be the most exposed to damaging ROS effects during storage.

Pedunculate oak (Quercus robur L.) is a long-lived, deciduous tree important in European forests [29]. Pedunculate oak acorns display recalcitrance, and recommended storage conditions involve a temperature of $-3{ }^{\circ} \mathrm{C}$ and a moisture content (MC) of $40 \%$ [13]. Acorns of pedunculate oak are usually stored for one to three years [30,31], and the maximal storage time, five years, was reported in only one laboratory [32,33]. To overcome obstacles in traditional recalcitrant seed storage, a cryogenic storage protocol for pedunculate oak was developed using plumules (a small apical meristem) isolated from an embryonic axis [34] and embryogenic calli derived from immature zygotic embryos [35]. However, to meet targets in biodiversity conservation and genebanking programs, the development of a less expensive traditional storage protocol for pedunculate oak seeds is needed. Especially in Europe, mast years usually occur in 3-8 year intervals, reinforcing the need for long-term storage [13]. Investigations of the sensitivity of pedunculate oak seeds to freezing temperatures revealed that ice crystallization, and consequently tissue death, occurs at temperatures of $-8^{\circ} \mathrm{C}$ and $-10^{\circ} \mathrm{C}$ and further revealed that $-9{ }^{\circ} \mathrm{C}$ is a critical freezing temperature [36]. As a result, temperatures down to $-7^{\circ} \mathrm{C}$ were discovered to be nondestructive for pedunculate oak acorns characterized with $42-43 \%$ MC [36], encouraging us to design experiments involving ROS detection at previ- 
ously unexplored storage temperatures. The aging rate depends on the storage temperature and chemical composition of seeds $[37,38]$. The chemical composition of pedunculate oak seeds includes mainly carbohydrates, proteins, tannins, and oils, and the latter ones comprise $5.2-5.6 \%$ [39]. Particularly the auto-oxidation of lipids can result in oxidative damage of molecules because oil droplets can remain fluid at low temperatures [40].

This investigation was designed to answer the question of how to manipulate the temperature to limit ROS production and prolong storage time, sustaining high seed quality by implementing heat treatment before storage and lower than recommended constant storage temperatures and combinations of storage temperatures leading to cold acclimation.

\section{Materials and Methods}

\subsection{Material}

Seeds of pedunculate oak (Quercus robur L.), originating from three provenances, Białogard ( $54^{\circ} 00^{\prime} \mathrm{N} 15^{\circ} 59^{\prime}$ E), Kobiór ( $\left(50^{\circ} 03^{\prime} \mathrm{N} 18^{\circ} 56^{\prime}\right.$ E) and Parczew $\left(51^{\circ} 38^{\prime} \mathrm{N} 22^{\circ} 54^{\prime} \mathrm{E}\right)$, in Poland were analyzed. Acorns exhibited $40-42 \%$ moisture content after collection and before storage and displayed germination capacities of 100, 96 and 94\% in the Białogard, Kobiór and Parczew provenances, respectively.

\subsection{Temperature Manipulations before and during Storage}

\subsubsection{Thermotherapy}

Only acorns of provenance Kobiór were subjected to thermotherapy before storage. Thermotherapy was conducted by aerated steam for $2.5 \mathrm{~h}$ at $41^{\circ} \mathrm{C}$ as described by Delatour et al. [12] and confirmed by Kranjec Orlović et al. [16] when selecting the best time vs. temperature combination. All biochemical measurements were performed immediately after cooling seeds to room temperature (RT).

\subsubsection{Acclimation to Lower Temperature}

Acorns of all three provenances were stored for 3 months (mths) at each constant temperature $-3{ }^{\circ} \mathrm{C},-5^{\circ} \mathrm{C}$, or $-7{ }^{\circ} \mathrm{C}$ and at combined temperatures, which we call here cold acclimation $\left(-3^{\circ} \mathrm{C} / 1 \mathrm{mth} \rightarrow-5^{\circ} \mathrm{C} / 2 \mathrm{mths}\right.$ or $-3^{\circ} \mathrm{C} / 1 \mathrm{mth} \rightarrow-5^{\circ} \mathrm{C} / 1 \mathrm{mth} \rightarrow$ $-7^{\circ} \mathrm{C} / 1 \mathrm{mth}$ ) when acorns were transferred to each lower temperature after one month of acclimation.

\subsection{Determination of ROS Release}

Most Quercus species studies use excised embryonic axes [41]. Ten embryonic axes excised from pedunculate oak acorns in six biological replicates were used as seed samples in our experiments. The increase in ROS production, termed extracellular bursts of ROS, is induced by various physiological transitions and stress conditions in recalcitrant seeds [26], including embryonic axes of pedunculate oak seeds [42]. Therefore, the determination of extracellular production of ROS was recommended for excised embryonic axes of recalcitrant seeds [43]. Absorbance and fluorescence were measured using an Infinite M200 PRO (Tecan, Männedorf, Switzerland) plate reader and Magellan software.

\subsubsection{Release of Hydrogen Peroxide $\left(\mathrm{H}_{2} \mathrm{O}_{2}\right)$}

The level of $\mathrm{H}_{2} \mathrm{O}_{2}$ was measured according to the method of Schopfer et al. [44]. Seed samples were incubated in $1.2 \mathrm{~mL}$ of reaction buffer containing $20 \mathrm{mM}$ phosphate buffer ( $\mathrm{pH}$ 6), $5 \mu \mathrm{M}$ scopoletin, and $1 \mathrm{U} \mathrm{mL}^{-1}$ peroxidase in darkness on a shaker at $150 \mathrm{rpm}$ for $1 \mathrm{~h}$ at RT. Fluorescence was measured at an excitation wavelength of $346 \mathrm{~nm}$ and an emission wavelength of $455 \mathrm{~nm}$. The results are shown in picomoles of $\mathrm{H}_{2} \mathrm{O}_{2}$ per gram of fresh weight (FW) per hour. 


\subsubsection{Release of Superoxide Anion Radical $\left(\mathrm{O}_{2}{ }^{\bullet-}\right)$}

The release of the level of $\mathrm{O}_{2}{ }^{\bullet-}$ was determined using a method described by Choi et al. [45]. Seed samples were incubated in $1.2 \mathrm{~mL}$ solution consisting of $50 \mathrm{mM}$ phosphate buffer (pH 7.8), 0.05\% nitro blue tetrazolium (NBT; Sigma, St. Louis, MO, USA), and $10 \mathrm{mM}$ sodium azide. After $30 \mathrm{~min}$ incubation at RT in darkness, the reactive solution was heated for $30 \mathrm{~min}$ at $85^{\circ} \mathrm{C}$, cooled and centrifuged for $3 \mathrm{~min}$ at $14,000 \mathrm{rpm}$. The precipitate was dissolved in dimethyl sulfoxide (DMSO) containing $2 \mathrm{M} \mathrm{KOH}$ by shaking for $30 \mathrm{~min}$ at $150 \mathrm{rpm}$ and vortexing every $5 \mathrm{~min}$. Absorbance at $719 \mathrm{~nm}$ was measured. The results are presented as $\Delta \mathrm{A}_{719}$ values per gram of FW per hour.

\subsubsection{Release of Hydroxyl Radical $(\bullet \mathrm{OH})$}

The level of $\bullet \mathrm{OH}$ was determined according to the method described by Schopfer et al. [44]. Seed samples were incubated for $3 \mathrm{~h}$ at RT (darkness, shaking at $150 \mathrm{rpm}$ ) in $1.2 \mathrm{~mL}$ of a reaction mixture containing $20 \mathrm{mM}$ phosphate buffer $(\mathrm{pH} 6)$ and $2.5 \mathrm{mM}$ sodium benzoate. Fluorescence was measured at an excitation wavelength of $305 \mathrm{~nm}$ and an emission wavelength of $407 \mathrm{~nm}$. The results were expressed in relative fluorescence units (RFU) per gram of FW per hour.

\subsection{Seed Viability Determination}

\subsubsection{Germination Test (Hypocotyl Emergence)}

Cut acorns (one-third of the distal end was removed) were sown vertically in plastic boxes [46] in 3 repetitions of 30 seeds in a medium $(1: 1, v / v)$ consisting of quartz sand $(<1 \mathrm{~mm}$ fraction) and sieved peat ( $\mathrm{pH}$ 5.5-6.5). The apical portion of the acorns containing an embryonic axis was aboveground to allow observation of germination. Seeds with a radicle at least $5 \mathrm{~mm}$ long were considered germinated [13].

\subsubsection{Seedling Emergence (Epicotyl Emergence)}

Cut acorns, three repetitions of 30 seeds each, were sown in the above described medium and covered with a lid at $20^{\circ} \mathrm{C}$ and a $16 / 8 \mathrm{~h}$ photoperiod under a light intensity of $60 \mathrm{mmol} \mathrm{m}^{-2} \mathrm{~s}^{-1}$ provided by a fluorescent lamp (Fluora, Osram ${ }^{\mathrm{TM}}$ ). When the shoot was at least $2-5 \mathrm{~cm}$ long with its first leaves on the top, the seedling was classified as emerged.

\subsubsection{Electrolyte Leakage}

Three samples of five seeds (the pericarp was removed) were placed in $10 \mathrm{~mL}$ of deionized water and left for $24 \mathrm{~h}$ at RT, and then the electric conductivity (EC) of the solutions $\left(\mathrm{C}_{0}\right)$ was measured with a conductometer (SvenCompact S230, Mettler Toledo, Switzerland). The results obtained were expressed in $\mathrm{mS}^{*} \mathrm{~g}^{-1}$ of FW. Then, the seeds were brought to the boil and left for $24 \mathrm{~h}$ at RT to measure $\mathrm{C}_{1}$ to calculate the percentage of electrolyte outflow using the formula $\left(\mathrm{C}_{0} /\left(\mathrm{C}_{0}+\mathrm{C}_{1}\right)\right) * 100 \%$.

\subsection{Statistical Analyses}

All experiments were performed with three to six independent biological replicates. Statistically significant differences were tested using ANOVA and Tukey's test at $p>0.05$. Proportional data were arcsine transformed prior to analysis using $R$ statistical software to calculate Pearson's correlation coefficient [47]. Germination and seedling emergence were analyzed using a generalized linear model. The corrplot package was used to construct correlation matrices [48].

\section{Results}

The effect of seed thermotherapy on the release of three types of ROS was monitored (Figure 1). More precisely, the three types of $\mathrm{ROS}$ were $\mathrm{H}_{2} \mathrm{O}_{2}, \mathrm{O}_{2}{ }^{\bullet-}$ and $\bullet \mathrm{OH}$. Importantly, thermotherapy did not elevate the levels of released ROS types. After heat treatment, the levels of $\mathrm{O}_{2}{ }^{\bullet-}$ and $\bullet \mathrm{OH}$ were identical to the levels in nontreated seeds, while the level of $\mathrm{H}_{2} \mathrm{O}_{2}$ slightly decreased and was still comparable to the level in control seeds. Our study 
indicates that seed thermotherapy, used for the elimination of pathogens, does not elevate ROS levels in the initial steps of seed preparation for long-term storage, confirming that the ROS-based decrease in longevity is not intensified via this heat treatment.
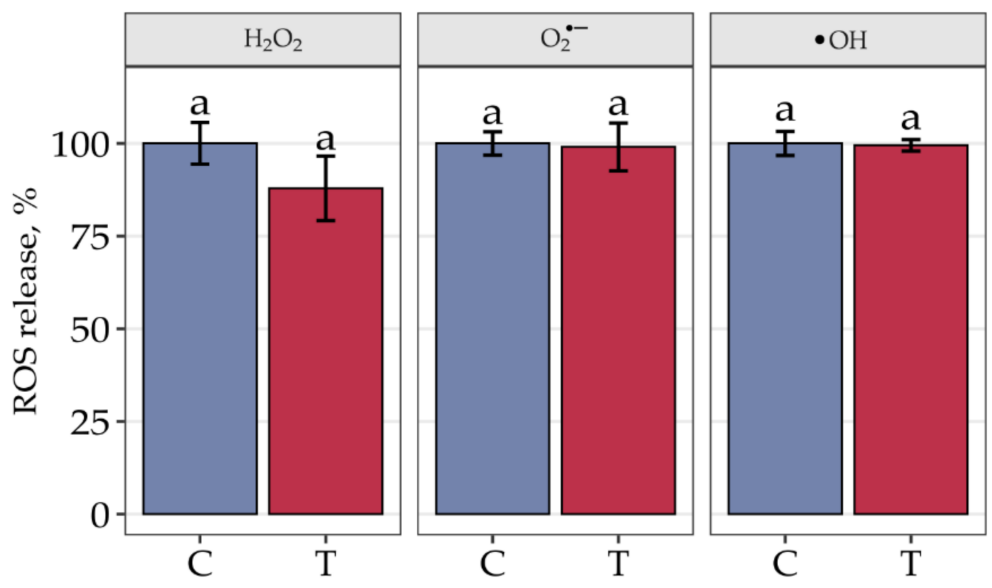

Figure 1. The release of three types of ROS hydrogen peroxide $\left(\mathrm{H}_{2} \mathrm{O}_{2}\right)$, superoxide anion radical $\left(\mathrm{O}_{2}{ }^{\bullet-}\right)$ and hydroxyl radical $(\bullet \mathrm{OH})$ in embryonic axes of pedunculate oak control seeds $(\mathrm{C})$ and seeds subjected to thermotherapy $(\mathrm{T})$. The data are the means of six independent replicates \pm the SE. The same letters indicate groups that are not significantly different according to Tukey's test.

Short-term stored seeds at constant temperature displayed increased ROS levels as the temperature was lowered (Figure 2). More specifically, seeds stored at $-7^{\circ} \mathrm{C}$ contained much higher levels of $\mathrm{H}_{2} \mathrm{O}_{2}, \mathrm{O}_{2}{ }^{\bullet-}$ and $\bullet \mathrm{OH}$, except the levels of $\mathrm{H}_{2} \mathrm{O}_{2}$ reported in Kobiór provenance (Figure $2 \mathrm{~b}$ ). Interestingly, the levels of $\bullet \mathrm{OH}$ continuously increased as the temperature was lowered, clearly indicating that each decrease of $2{ }^{\circ} \mathrm{C}$ resulted in elevated ROS production (Figure $2 \mathrm{~g}-\mathrm{i}$ ).

Keeping in mind that the lowest storage temperature, $-7^{\circ} \mathrm{C}$, rendered the highest ROS levels, an experiment was conducted in which seeds were progressively acclimated to cooler temperatures. In the majority, the two-step acclimation $-3{ }^{\circ} \mathrm{C} \rightarrow-5{ }^{\circ} \mathrm{C}$ did not significantly lower ROS levels compared to the seeds stored at a constant $-5{ }^{\circ} \mathrm{C}$ temperature. The three-step acclimation $-3{ }^{\circ} \mathrm{C} \rightarrow-5{ }^{\circ} \mathrm{C} \rightarrow-7{ }^{\circ} \mathrm{C}$ displayed a more beneficial effect, particularly in the levels of $\bullet \mathrm{OH}$, which decreased in all three provenances after acclimation to the levels reported at the constant $-5{ }^{\circ} \mathrm{C}$ temperature (Figure $2 \mathrm{~g}-\mathrm{i}$ ).

Importantly, the effect of seed provenance was most visible when investigating Kobiór origin. For instance, $\mathrm{H}_{2} \mathrm{O}_{2}$ levels did not increase at constant temperatures of -5 and $-7^{\circ} \mathrm{C}$ (Figure $2 \mathrm{~b}$ ), whereas the levels of $\mathrm{O}_{2}{ }^{\bullet-}$ and $\bullet \mathrm{OH}$ were clearly doubled at $-7^{\circ} \mathrm{C}$ (Figure 2e). Additionally, in seeds of Kobiór provenance, both the two- and three-step acclimation limited $\mathrm{O}_{2}{ }^{\bullet-}$ release to the levels observed at $-3{ }^{\circ} \mathrm{C}$ constant temperature (Figure 2h). Similarly, two-step acclimation limited $\bullet \mathrm{OH}$ release to the amount detected at $-3{ }^{\circ} \mathrm{C}$ constant temperature, and three-step acclimation limited $\bullet \mathrm{OH}$ release to the amount detected at $-5{ }^{\circ} \mathrm{C}$ constant temperature (Figure $2 \mathrm{~h}$ ).

Germination capacity and seedling emergence (Figure $3 \mathrm{~d}-\mathrm{f}$ ) were tested between provenances to assess the effect of storage temperatures on seed viability and to dissect whether ROS levels affect viability after short-term storage. Both germination and seedling emergence were the highest in seeds of Kobiór provenance after storage at $-3{ }^{\circ} \mathrm{C}$ and decreased at lower temperatures. Seeds of Białogard provenance displayed undifferentiated germination and seedling emergence. In contrast, seeds of Parczew provenance exhibited a linear decrease in seedling emergence together with a decrease in storage temperature. Importantly, cold acclimation strongly enhanced the germination rate and seedling emergence of seeds originating from Parczew provenance, reaching higher values than seeds stored at constant temperatures. The effect of cold acclimation was less visible in seeds of Kobiór provenance because both seed viability parameters were only slightly enhanced 
(Figure 3e). Measurements of EC revealed that seeds of Parczew provenance displayed almost triple electrolyte leakage when stored at constant $-7^{\circ} \mathrm{C}$. Notably, three-step cold acclimation to $-7^{\circ} \mathrm{C}$ halved EC (Figure $3 \mathrm{a}-\mathrm{c}$ ).

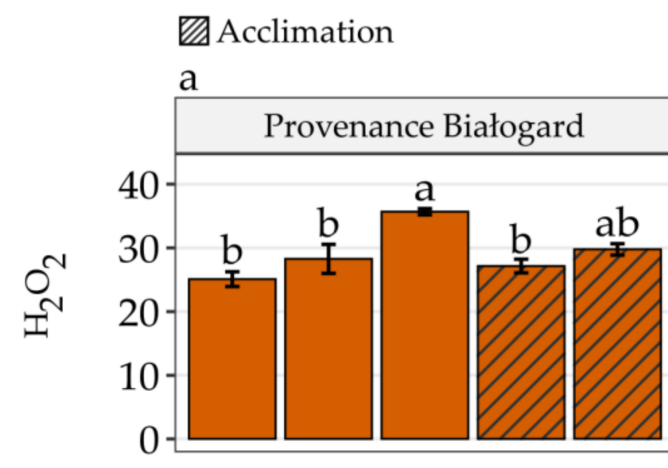

b
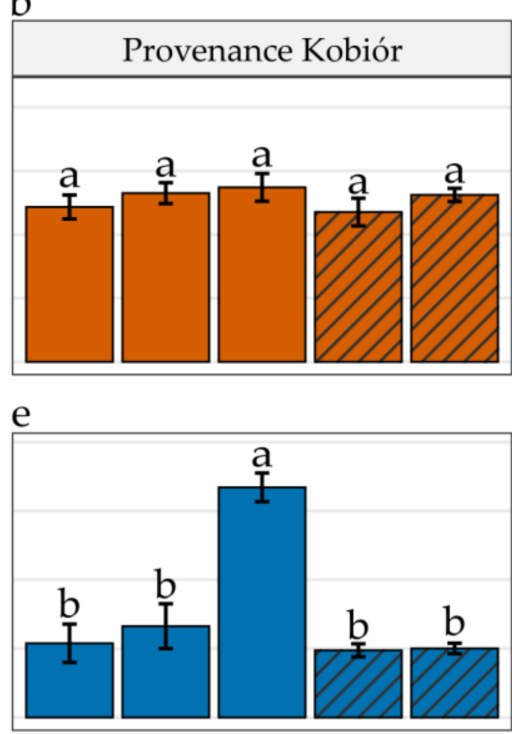

$\mathrm{h}$

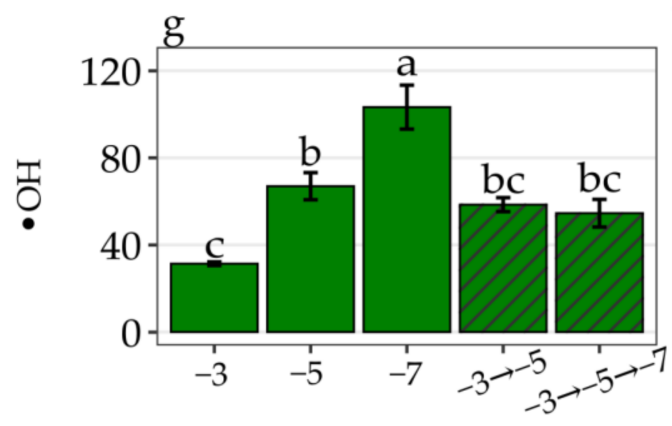

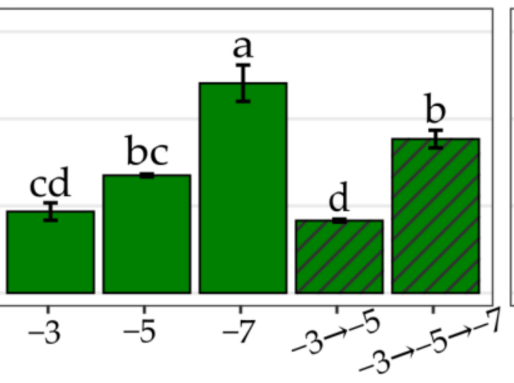
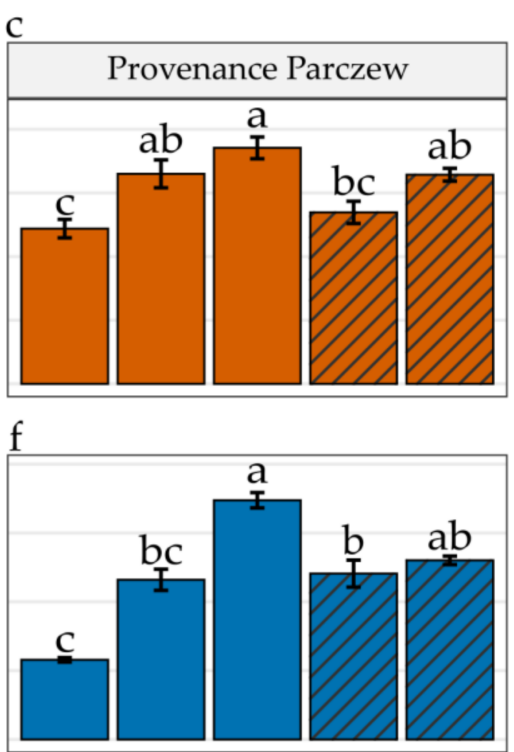

i

Temperature, ${ }^{\circ} \mathrm{C}$

Figure 2. Measurements of ROS release levels $(\mathbf{a}-\mathbf{c})$ hydrogen peroxide $\left(\mathrm{H}_{2} \mathrm{O}_{2}\right),(\mathbf{d}-\mathbf{f})$ superoxide anion radical $\left(\mathrm{O}_{2}{ }^{\bullet-}\right)$ and $(\mathrm{g}-\mathbf{i})$ hydroxyl radical $(\bullet \mathrm{OH})$ in embryonic axes of pedunculate oak acorns stored at single temperature $\left(-3^{\circ} \mathrm{C},-5^{\circ} \mathrm{C}\right.$, or $\left.-7^{\circ} \mathrm{C}\right)$ and at combined temperatures $\left(-3^{\circ} \mathrm{C} \rightarrow-5^{\circ} \mathrm{C}\right.$ or $\left.-3^{\circ} \mathrm{C} \rightarrow-5^{\circ} \mathrm{C} \rightarrow-7^{\circ} \mathrm{C}\right)$ and originating from three provenances: Białogard, Kobiór and Parczew. Units: $\mathrm{H}_{2} \mathrm{O}_{2}\left[\mathrm{nmol} \mathrm{g}{ }^{-1} \mathrm{FW} \mathrm{h}^{-1}\right], \mathrm{O}_{2}{ }^{\bullet-}\left[\Delta \mathrm{A} \mathrm{nmol} \mathrm{g}{ }^{-1} \mathrm{FW} \mathrm{h}^{-1}\right], \bullet \mathrm{OH}\left[\mathrm{RFU} 10^{3} \mathrm{~g}^{-1} \mathrm{FW} \mathrm{h}^{-1}\right]$. Data are the means of six independent replicates \pm the SE. Identical letters indicate groups not significantly differentiated according to Tukey's test.

Seedling emergence corresponded to germination capacity in all tested provenances being highly correlated in the provenance Parczew, in which the response to storage temperature changes manifested via ROS levels and seed viability determinants were the most remarkable (Figure 4).

Importantly, the correlation between the levels of $\mathrm{H}_{2} \mathrm{O}_{2}$ and $\mathrm{O}_{2}{ }^{--}$in seeds of each provenance equaled 1 . Additionally, the levels of released $\bullet \mathrm{OH}$ were strongly correlated with other ROS types in Białogard and Parczew provenances, and in the latter provenances, -OH levels were correlated with all seed viability determinants, indicating that increasing - $\mathrm{OH}$ levels results in a decrease in the germination rate and seedling performance and an increase in electrolyte leakage. 


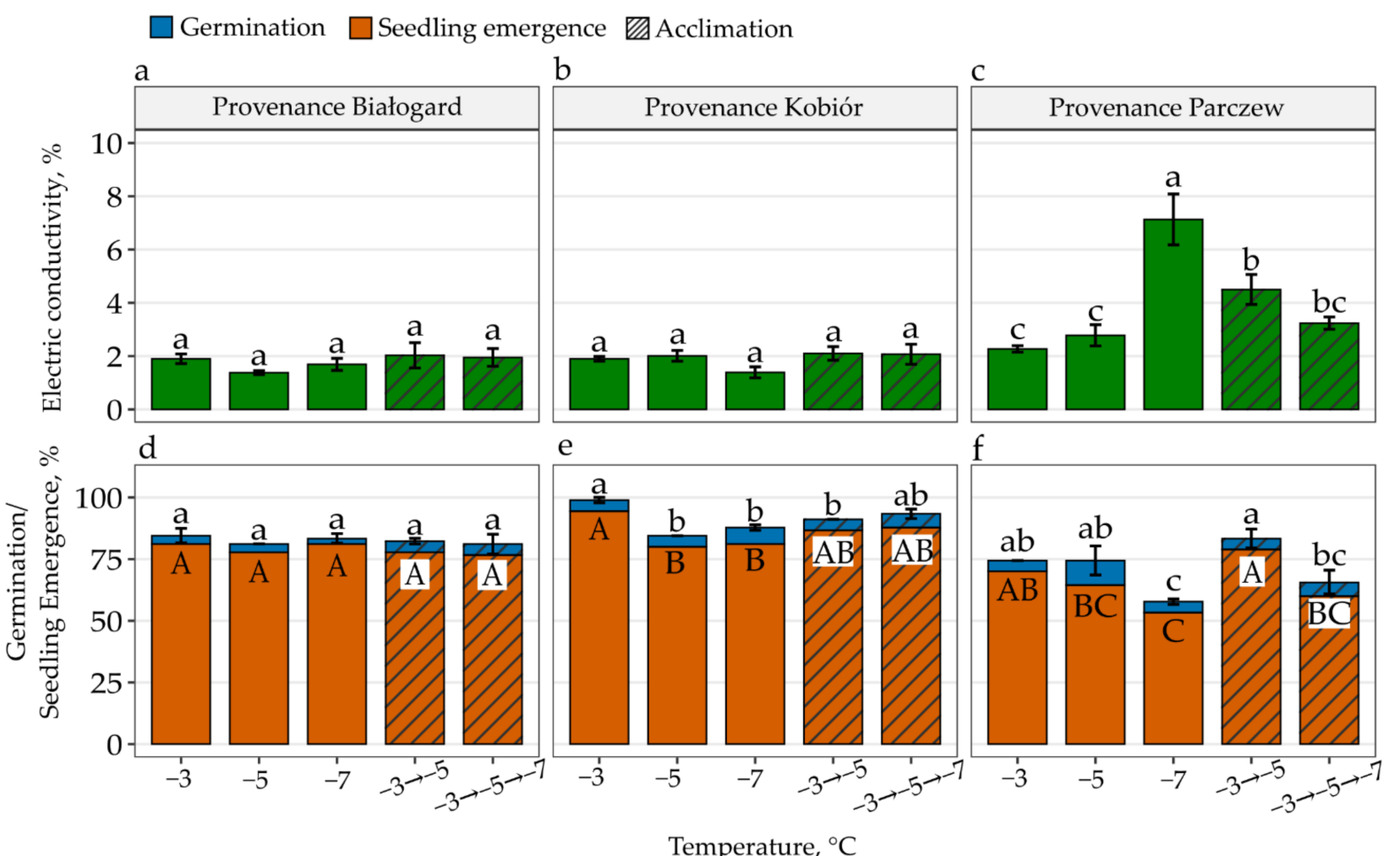

Figure 3. Seed viability determinants: $(\mathbf{a}-\mathbf{c})$ electric conductivity, $(\mathbf{d}-\mathbf{f})$ germination and seedling emergence in shortterm stored pedunculate oak seeds originating from three provenances Białogard, Kobiór and Parczew. Data are the means of three independent replicates \pm the SE. Identical letters indicate groups not significantly differentiated according to Tukey's test.
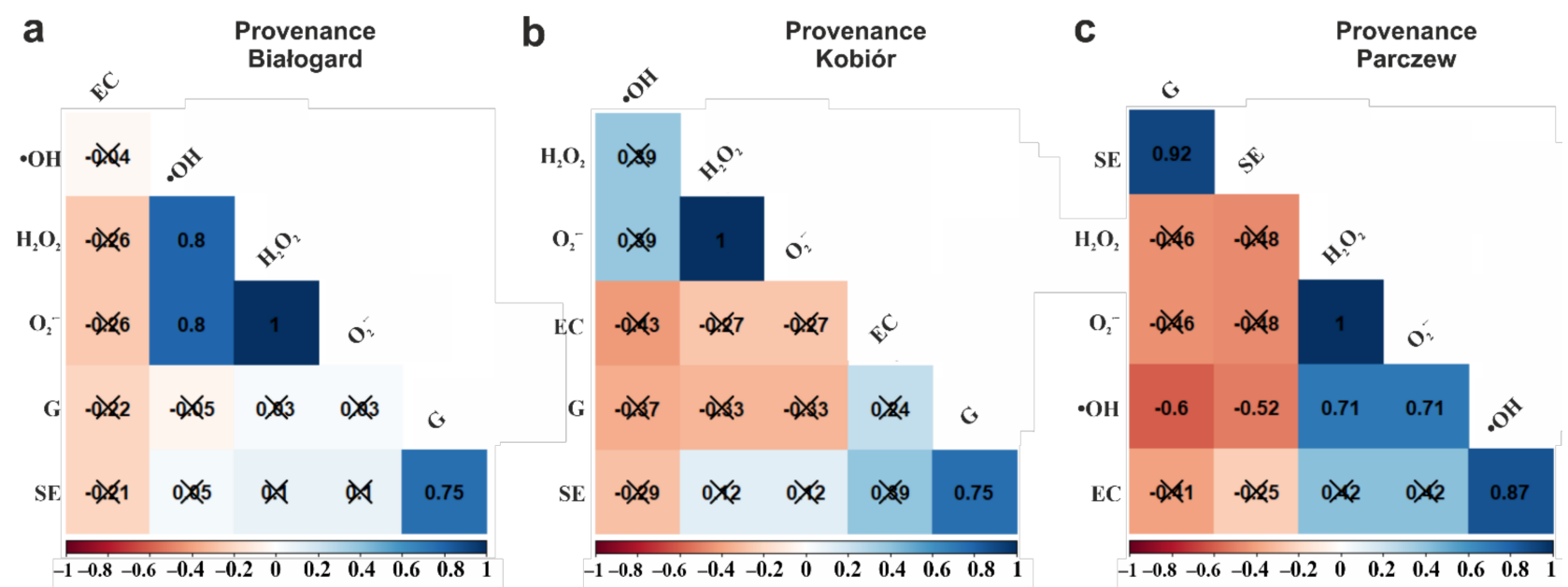

Figure 4. Correlation matrices calculated for pedunculate oak seeds originating from three provenances, (a) Białogard, (b) Kobiór and (c) Parczew, based on the levels of hydrogen peroxide $\left(\mathrm{H}_{2} \mathrm{O}_{2}\right)$, superoxide anion radical $\left(\mathrm{O}_{2}{ }^{\bullet-}\right)$, hydroxyl radical $(\bullet \mathrm{OH})$, electrical conductivity $(\mathrm{EC})$, germination capacity $(\mathrm{G})$ and seedling emergence (SE). The percentage of $\mathrm{G}, \mathrm{SE}$ and EC was ArcSin transformed. Crossed numbers indicate a nonsignificant correlation $(p>0.05)$. The more red the color is, the more negative the correlation, whereas the more blue, the more positive the correlation.

\section{Discussion}

Heat (high temperatures) stress is defined differently across studies in which heat duration and intensity vary [49]. Most likely, seeds of pedunculate oak subjected to thermotherapy underwent heat shock at a nonlethal high temperature, which induced 
thermotolerance and thus can be termed 'priming' [50]. Heat induces heat shock proteins (HSPs) [51,52] and heat-associated proteins [52], including transcription factors [53], all of which induce and modulate thermotolerance [51-53]. HSPs generally function as chaperones protecting protein folding and structure and preventing protein aggregation [51], while a class of small HSPs was also found to act in adaptation to oxidative stress [54]. Plants display different response patterns under heat shock and prolonged warming; however, increased ROS production, predominantly $\mathrm{H}_{2} \mathrm{O}_{2}$, and activation of antioxidant enzymes are characteristic of both types of heat events [55] being even more induced under heat shock conditions [56]. In this context, ROS levels were probably maintained at initial levels because the antioxidant systems were activated by heat stress (Figure 1).

$\mathrm{H}_{2} \mathrm{O}_{2}$ is a signaling molecule in the plant response to stress [57] and developmental transitions in seeds [23]. The levels of $\mathrm{H}_{2} \mathrm{O}_{2}$ were slightly decreased after thermotherapy in the embryonic axes of pedunculate oak (Figure 1). Interestingly, according to Wang et al. [56], the activities of the ROS scavenging enzymes superoxide dismutase (SOD), catalase (CAT) and peroxidase (POD) are significantly higher in response to heat shock in Arabidopsis thaliana. Additionally, the levels of phenolic compounds, predominantly carotenoids, and ascorbic acid (AsA), known to be involved in $\mathrm{H}_{2} \mathrm{O}_{2}$ removal, were reported to be elevated in heat shock [19]. Presumably, SOD, CAT, POD, AsA and carotenoids contributed to maintaining the physiological concentrations of $\mathrm{H}_{2} \mathrm{O}_{2}$ and other ROS types in pedunculate oak seeds (Figure 1). In this context, thermotherapy appears to be beneficial not only in pathogen limitations in oak acorns [13-16] but also in seed priming, resulting in increased physiological fitness. Seed coats display higher heat capacity and thermal conductivity and low thermal diffusivity [58]. Regarding the temperature gradient inside a seed, heat stress would be more harmful to larger cotyledons of pedunculate oak than to embryonic axes. Fortunately, removal of up to $60 \%$ of cotyledons at the basal end does not affect the germination capacity of oak acorns [59].

Seed recalcitrance complicates ex situ conservation of pedunculate oak species [60,61]. Regarding seed longevity, detoxification efficiency is one of the most essential mechanisms for seed vigor [20,62]. Recently, genome-wide association studies and reverse genetics indicated positive and negative genes for seed longevity, and the latter included ROSproducing oxidases, experimentally confirming that seed longevity is strongly related to oxidative stress [21]. In this context, seeds intended for storage should contain ROS levels not higher than physiological and as low as possible because oxidative damage by ROS was proposed to explain freezing injury [63]. Cold stress includes both chilling and freezing injury. Therefore, ROS levels (Figure 2) should be considered both in signaling and freezing injury terms, because ROS were demonstrated as important signaling molecules in plants during acclimation to high and low temperatures [64].

The reduction of molecular oxygen $\left(\mathrm{O}_{2}\right)$ leads to the production ofO $\mathrm{O}_{2}{ }^{\bullet-}$, which is the precursor to most other ROS types. In the dismutation reaction, $\mathrm{O}_{2}{ }^{\bullet-}$ is converted into $\mathrm{H}_{2} \mathrm{O}_{2}$, which produces $\bullet \mathrm{OH}$ when the reduction reaction is only partial. $\bullet \mathrm{OH}$ is acknowledged as a potent regulator in plant cell biology [65]. $\bullet \mathrm{OH}$ was the ROS type that clearly responded to changes in storage temperatures (Figure $2 \mathrm{~g}$-i). Plants can generate extracellular $\bullet \mathrm{OH}$ via cell wall-bound and plasma membrane-bound class III heme-containing peroxidases (PODs) in the Haber-Weiss reaction from $\mathrm{H}_{2} \mathrm{O}_{2}$ and $\mathrm{O}_{2}{ }^{\bullet-}$ [44]. Possibly, pools of $\mathrm{H}_{2} \mathrm{O}_{2}$ and $\mathrm{O}_{2}{ }^{--}$did not display a linear increase in embryonic axes of pedunculate oak acorns stored at constant $-3,-5$ and $-7^{\circ} \mathrm{C}$ temperatures because PODs partially consumed them and transformed into the $\bullet \mathrm{OH}$ form (Figure 2a-f). Pedunculate oak seeds, similarly to other recalcitrant seeds, are metabolically active throughout storage [26]; therefore, the activity of antioxidant enzymes can be additionally regulated via temperature and genetic diversity between provenances.

There are no enzymes to administer $\bullet \mathrm{OH}$, which is the most reactive and short-lived among all ROS radicals. In this context, the levels of released $\bullet \mathrm{OH}$ might be suggested as a good indicator of the seed response to colder storage temperatures. To support this hypothesis, Laohavisit et al. [66] identified $\bullet \mathrm{OH}$ as an effector in stress cellular signaling 
based on calcium. The suggested positive role of $\bullet \mathrm{OH}$ in adaptation to stress [65] can be manifested here via reduced levels of $\bullet \mathrm{OH}$ when seeds were transferred from -3 to -5 and eventually to $-7^{\circ} \mathrm{C}$ (Figure $2 \mathrm{~g}-\mathrm{i}$ ), emphasizing seed acclimation to freezing stress. In particular, $\bullet \mathrm{OH}$ formation was previously reported in the stems of winter wheat treated with freezing temperature [67]. Furthermore, $\bullet \mathrm{OH}$ levels were correlated with seed viability parameters in the Parczew provenance (Figure 4c), the provenance in which the viability loss was the most spectacular. We speculate that changes in $\bullet \mathrm{OH}$ levels are an early predictor of subsequent decreases in germination rates and seedling emergence that were reported in pedunculate oak acorns stored at -5 and $-7{ }^{\circ} \mathrm{C}$ [68] for above 6 months (personal communication).

Interestingly, the correlation between $\mathrm{O}_{2}{ }^{-}-$and $\mathrm{H}_{2} \mathrm{O}_{2}$ levels equaled 1 in all tested provenances (Figure 4); therefore, $\mathrm{SOD}$, a group of enzymes catalyzing the dismutation of $\mathrm{O}_{2}{ }^{\bullet-}$ into $\mathrm{H}_{2} \mathrm{O}_{2}$, should be explored in more detail. Manganese-dependent SOD (MnSOD) seems to be the most efficient antioxidant enzyme against freezing stress [69]. The number of SOD isoforms and their activity render the tolerance level of plants [70]. It is possible that SOD activity eliminated excessive $\mathrm{O}_{2}{ }^{\bullet-}$ in seeds of Kobiór provenance stored at $-5^{\circ} \mathrm{C}$ to the level reported at $-3^{\circ} \mathrm{C}$ and therefore was a major contributor that sustained these low $\mathrm{O}_{2}{ }^{\bullet-}$ levels when seeds were subjected to two- and three-step acclimation processes (Figure 2e). Only acorns from Kobiór provenance underwent thermotherapy procedures, which as a result increased their tolerance to heat stress. At the same time, the acclimation process probably enhanced the activity of antioxidant enzymes.

CAT was assumed to be a seed viability determinant in 1929 [71]. CAT scavenges the majority of $\mathrm{H}_{2} \mathrm{O}_{2}$, as known from studies of catalase-deficient and catalase-overexpressing plants [72]. The $\mathrm{H}_{2} \mathrm{O}_{2}$ levels were uniquely unchanged in the embryonic axes of Kobiór provenance seeds (Figure 2b), indicating that an excellent $\mathrm{H}_{2} \mathrm{O}_{2}$ homeostasis system was possibly induced via thermotherapy and sustained in short-term stored seeds. Interestingly, $\mathrm{H}_{2} \mathrm{O}_{2}$ and nitric oxide (NO) cross-react and generate $\bullet \mathrm{OH}$ [73], depleting the detectable pool of $\mathrm{H}_{2} \mathrm{O}_{2}$ more. Furthermore, NO-mediated S-nitrosylated CAT activity might be decreased [74], particularly when NO would be less effectively eliminated via reaction in $\mathrm{H}_{2} \mathrm{O}_{2}$, a situation that can be postulated for Białogard and Parczew provenance seeds (Figure 2a,c). Additionally, provenances can exhibit different levels of genotypic diversity [75]. Therefore, different levels of ROS as a response to freezing injury were detected in this study when comparing three different provenances (Figure 2). Similarly, recalcitrant seeds collected from various provenance differs in terms of chilling tolerance [76].

The use of high-quality planting material guarantees the success of seed-based restoration programs [77], and selection of forest restoration material with priority areas for sourcing seeds can be supported by provenance comparisons reported in our studies (Figure 2) because oxidation processes reported in stored seeds are transferred to seedlings [27]. Provenance selection determines the growth performance of $Q$. robur [78]; in this context, seeds of Parczew provenance quickly losing vitality should not be considered for long-term storage and reforestation purposes. Moreover, pedunculate oak seedlings display provenance-dependent growth responses under a changing climate with air warming and drought [79]. In this context, ROS levels, particularly $\bullet \mathrm{OH}$, should be considered in storage protocols for quality control. Seeds of the three provenances Białogard, Kobiór and Parczew contained very similar ROS levels when stored for a short time at the recommended constant $-3^{\circ} \mathrm{C}$ and elevated to almost identical levels when subjected to freezing injury at $-7^{\circ} \mathrm{C}$, being three times (Figure $2 \mathrm{~d}-\mathrm{f}$ ) and up to five times higher, supposing $\bullet \mathrm{OH}$ (Figure $2 \mathrm{~g}-\mathrm{i}$ ). The observed differences in cold stress acclimation manifested in ROS levels might be the effect of intraspecific diversity between the three analyzed provenances. Seeds of the Parczew provenance were of poor quality, as shown in all seed viability parameters (Figure 3). In addition to poor germination and seedling performance, EC indicated freezing injury at $-7^{\circ} \mathrm{C}$ (Figure 3c). EC reflects the integrity of the membranes and is therefore a recommended indicator of vigor and eventually longevity of the seeds [80]. Ice-binding 
proteins, termed antifreezing proteins (AFPs), confer freezing tolerance [81]. Observed deterioration of membranes at $-7^{\circ} \mathrm{C}$ was the effect of weaker freezing tolerance in seeds of Parczew provenance, which possibly resulted from faster aging process related to insufficient activity of AFP reflected in linear increase of each type of ROS at lower and lower constant storage temperatures (Figure 2c,f,i). Among the other two provenances, the beneficial effect of thermotherapy and cold acclimation contributed to higher germination rates and better seedling performance as well as to the dynamics of ROS production (Figures 1 and 2). Seeds of the Kobiór provenance appeared to be the most suitable forest restoration material and possibly will sustain high viability after long-term storage, which will be monitored in future studies.

\section{Conclusions}

The detrimental role of ROS is apparent in long-term stored seeds. Therefore, protocols should be modified with higher awareness of this problem. Thermotherapy turned out to be beneficial not only in relation to pathogen, mainly fungi, riddance but also for ROS balance and seed viability. In this context, $\mathrm{H}_{2} \mathrm{O}_{2}$ homeostasis is the long-term effect of thermotherapy in stored seeds for up to 3 months. Consequently, the levels of $\bullet \mathrm{OH}$, an ROS type for which no dispatching enzyme exists, should be considered a new method of seed quality standard control under storage. Thermotherapy and gradual cold acclimation to storage temperature are promising procedures for pedunculate oak short-term storage at freezing temperatures; however, long-term storage experiments must be carried out to postulate the change in storage temperature and the process of acquaintance with the final storage temperature.

Author Contributions: Conceptualization, E.M.K., M.K.W., J.S. and P.C.; methodology, E.M.K. and J.S.; investigation, E.M.K. and M.K.W.; data analysis, E.M.K., M.K.W., J.S. and P.C., data curation and statistical analysis, E.M.K. and M.K.W.; writing—original draft preparation, E.M.K.; writing—review and editing, E.M.K., M.K.W., J.S. and P.C.; visualization, E.M.K. and M.K.W.; supervision, P.C.; project administration, P.C.; funding acquisition, P.C. All authors have read and agreed to the published version of the manuscript.

Funding: This research was funded by the General Directorate of State Forest (Poland), grant number EO.271.3.7.2018. The additional financial support was provided by the Institute of Dendrology, Polish Academy of Sciences.

Acknowledgments: The authors would like to thank Elżbieta Nogajewska, Danuta Szymańska, Magdalena Sobczak, Agata Obarska, Paulina Pilarz and Danuta Ratajczak for technical assistance in conducting all experiments.

Conflicts of Interest: The funders had no role in the design of the study; in the collection, analyses, or interpretation of data; in the writing of the manuscript, or in the decision to publish the results.

\section{References}

1. Buckley, L.B.; Huey, R.B. How Extreme Temperatures Impact Organisms and the Evolution of Their Thermal Tolerance. Integr. Comp. Biol. 2016, 56, 98-109. [CrossRef]

2. Kaspari, M.; Clay, N.A.; Lucas, J.; Yanoviak, S.P.; Kay, A. Thermal Adaptation Generates a Diversity of Thermal Limits in a Rainforest Ant Community. Glob. Chang. Biol. 2015, 21, 1092-1102. [CrossRef]

3. Gilchrist, G. Chapter 5 The Evolution of Thermal Sensitivity in Changing Environments. Cell Mol. Response Stress 2000, 1, 55-70. [CrossRef]

4. Mercer, J. Glossary of Terms for Thermal Physiology, Third Edition. Jpn. J. Physiol. 2001, 51, 245-280.

5. Wahid, A.; Gelani, S.; Ashraf, M.; Foolad, M.R. Heat Tolerance in Plants: An Overview. Environ. Exp. Bot. 2007, 61, 199-223. [CrossRef]

6. Kidokoro, S.; Yoneda, K.; Takasaki, H.; Takahashi, F.; Shinozaki, K.; Yamaguchi-Shinozaki, K. Different Cold-Signaling Pathways Function in the Responses to Rapid and Gradual Decreases in Temperature. Plant Cell 2017, 29, 760-774. [CrossRef]

7. Ding, Y.; Shi, Y.; Yang, S. Advances and Challenges in Uncovering Cold Tolerance Regulatory Mechanisms in Plants. New Phytol. 2019, 222, 1690-1704. [CrossRef]

8. Fallik, E.; Ilić, Z. The Influence of Physical Treatments on Phytochemical Changes in Fresh Produce after Storage and Marketing. Agronomy 2021, 11, 788. [CrossRef] 
9. Ellis, J.B.; Martin, G.B. Macrosporium solani E\&M. Am. Nat. 1882, 16, 1003.

10. Schröder, T.; Kehr, R.; Procházková, Z.; Sutherland, J.R. Practical Methods for Estimating the Infection Rate of Quercus robur Acorn Seedlots by Ciboria batschiana. For. Pathol. 2004, 34, 187-196. [CrossRef]

11. Merouani, H.; Trubat, R.; Lourenco, M.; Sampaio, T.; Santos, M.; Cortina, J.; Pereira, J.; Almeida, M.H. Fungus Development, a Factor Limiting the Long-Term Storage of Cork Oak Acorns. IOBC WPRS Bull. 2005, 28, 129.

12. Delatour, C.; Muller, C.; Bonnet-Masimbert, M. Progress in Acorns Treatment in a Long Term Storage Prospect. In Proceedings of the International Symposium on Forest Tree Seed Storage, Chalk River, ON, Canada, 23-27 September 1980.

13. Suszka, B.; Muller, C.; Bonnet-Masimbert, M.; Gordon, A. Seeds of Forest Broadleaves: From Harvest to Sowing; Institute National de la Recherche Agronomique: Paris, France, 1996; ISBN 978-2-7380-0659-2.

14. Finch-Savage, W.; Clay, H.; Budge, S.; Dent, K.; Clarkson, J.; Whipps, J. Biological Control of Sclerotinia Pseudotuberosa and Other Fungi During Moist Storage of Quercus robur Seeds. Eur. J. Plant Pathol. 2003, 109, 615-624. [CrossRef]

15. Knudsen, I.; Thomsen, K.; Jensen, B.; Poulsen, K. Effects of Hot Water Treatment, Biocontrol Agents, Disinfectants and a Fungicide on Storability of English Oak Acorns and Control of the Pathogen, Ciboria batschiana. For. Pathol. 2004, 34, 47-64. [CrossRef]

16. Kranjec Orlović, J.; Drvodelić, D.; Vukelić, M.; Rukavina, M.; Diminić, D.; Oršanić, M. Impact of Thermotherapy and Short-Term Storage on Quercus robur L. Acorn Mycobiota and Germination. Forests 2021, 12, 528. [CrossRef]

17. Suzuki, N.; Mittler, R. Reactive Oxygen Species and Temperature Stresses: A Delicate Balance between Signaling and Destruction. Physiol. Plant. 2006, 126, 45-51. [CrossRef]

18. Pandey, P.; Ramegowda, V.; Senthil-Kumar, M. Shared and Unique Responses of Plants to Multiple Individual Stresses and Stress Combinations: Physiological and Molecular Mechanisms. Front. Plant Sci. 2015, 6, 723. [CrossRef]

19. Loayza, F.E.; Brecht, J.K.; Simonne, A.H.; Plotto, A.; Baldwin, E.A.; Bai, J.; Lon-Kan, E. Enhancement of the Antioxidant Capacity of Ripe Tomatoes by the Application of a Hot Water Treatment at the Mature-Green Stage. Postharvest Biol. Technol. 2020, 161, 111054. [CrossRef]

20. Rajjou, L.; Debeaujon, I. Seed Longevity: Survival and Maintenance of High Germination Ability of Dry Seeds. C. R. Biol. 2008, 331, 796-805. [CrossRef]

21. Renard, J.; Niñoles, R.; Martínez-Almonacid, I.; Gayubas, B.; Mateos-Fernández, R.; Bissoli, G.; Bueso, E.; Serrano, R.; Gadea, J Identification of Novel Seed Longevity Genes Related to Oxidative Stress and Seed Coat by Genome-Wide Association Studies and Reverse Genetics. Plant Cell Environ. 2020, 43, 2523-2539. [CrossRef]

22. Harman, D. Aging: A Theory Based on Free Radical and Radiation Chemistry. J. Gerontol. 1956, 11, 298-300. [CrossRef]

23. Bailly, C. The Signalling Role of ROS in the Regulation of Seed Germination and Dormancy. Biochem. J. 2019, 476, 3019-3032. [CrossRef]

24. Jeevan Kumar, S.P.; Rajendra Prasad, S.; Banerjee, R.; Thammineni, C. Seed Birth to Death: Dual Functions of Reactive Oxygen Species in Seed Physiology. Ann. Bot. 2015, 116, 663-668. [CrossRef]

25. Walters, C. Orthodoxy, Recalcitrance and in-between: Describing Variation in Seed Storage Characteristics Using Threshold Responses to Water Loss. Planta 2015, 242, 397-406. [CrossRef]

26. Berjak, P.; Pammenter, N.W. Implications of the Lack of Desiccation Tolerance in Recalcitrant Seeds. Front. Plant Sci. 2013, 4, 478. [CrossRef]

27. Wawrzyniak, M.K.; Kalemba, E.M.; Ratajczak, E.; Chmielarz, P. Oxidation Processes Related to Seed Storage and Seedling Growth of Malus sylvestris, Prunus avium and Prunus padus. PLoS ONE 2020, 15, e0234510. [CrossRef]

28. Kalemba, E.M.; Suszka, J.; Ratajczak, E. The Role of Oxidative Stress in Determining the Level of Viability of Black Poplar (Populus nigra) Seeds Stored at Different Temperatures. Funct. Plant Biol. FPB 2015, 42, 630-642. [CrossRef]

29. Doody, C.N.; O’Reilly, C. Drying and Soaking Pretreatments Affect Germination in Pedunculate Oak. Ann. For. Sci. 2008, 65, 509. [CrossRef]

30. GOSLING, P.G. The Effect of Drying Quercus robur Acorns to Different Moisture Contents, Followed by Storage, Either with or without Imbibition. For. Int. J. For. Res. 1989, 62, 41-50. [CrossRef]

31. Ozbingol, N. Increasing Acorn Moisture Content Followed by Freezing-Storage Enhances Germination in Pedunculate Oak. Forestry 2005, 78, 73-81. [CrossRef]

32. Suszka, B.; Tylkowski, T. Storage of Acorns of the English Oak (Quercus robur L.) over 1-5 Winters. Arbor. Kornickie 1980, 25, 199-229.

33. Tylkowski, T. Height Increment of 1-Year Shoots of the English Oak (Quercus robur L.) and the Northern Red Oak (Quercus borealis Michx $=$ Q. rubra L.) from 4-Year-Old Roots of Seedlings Raised from Acorns Stored over 1-5 Winters. Arbor. Kórn. 1982, 27, 357-365.

34. Chmielarz, P.; Michalak, M.; Pałucka, M.; Wasileńczyk, U. Successful Cryopreservation of Quercus robur Plumules. Plant Cell Rep. 2011, 30, 1405-1414. [CrossRef] [PubMed]

35. Chmielarz, P.; Grenier-de March, G.; Boucaud, M.-T. Cryopreservation of Quercus robur L. Embryogenic Calli. Cryo Lett. 2005, 26, 349-356. [PubMed]

36. Chmielarz, P. Frost resistance of Quercus robur L. acorns. In Treatment and Storage of Oak Seeds. Present Situation and Research; Mitt.Biol.Bundesanst.Land-Forstwirtsch: Berlin-Dahlem, Germany, 1997; pp. 76-81.

37. Ballesteros, D.; Hill, L.M.; Lynch, R.T.; Pritchard, H.W.; Walters, C. Longevity of Preserved Germplasm: The Temperature Dependency of Aging Reactions in Glassy Matrices of Dried Fern Spores. Plant Cell Physiol. 2019, 60, 376-392. [CrossRef] 
38. Taylor, A.G. Seed Storage, Germination, Quality, and Enhancements. In Physiology of Vegetable Crops, 2nd ed.; Wien, H.C., Stuetzel, H., Eds.; CAB International: Wallingford, UK, 2020; p. 496, ISBN 978-1786393777.

39. Petrovic, S.; Sobajic, S.; Rakic, S.; Tomic, A.; Kukic, J. Investigation of Kernel Oils of Quercus robur and Quercus cerris. Chem. Nat. Compd. 2004, 40, 420-422. [CrossRef]

40. Ballesteros, D.; Pritchard, H.W.; Walters, C. Dry Architecture: Towards the Understanding of the Variation of Longevity in Desiccation-Tolerant Germplasm. Seed Sci. Res. 2020, 30, 142-155. [CrossRef]

41. Xia, K.; Hill, L.M.; Li, D.-Z.; Walters, C. Factors Affecting Stress Tolerance in Recalcitrant Embryonic Axes from Seeds of Four Quercus (Fagaceae) Species Native to the USA or China. Ann. Bot. 2014, 114, 1747-1759. [CrossRef]

42. Hendry, G.A.F. Oxygen, Free Radical Processes and Seed Longevity. Seed Sci. Res. 1993, 3, 141-153. [CrossRef]

43. Varghese, B.; Sershen, N.; Berjak, P.; Varghese, D.; Pammenter, N.W. Differential Drying Rates of Recalcitrant Trichilia dregeana Embryonic Axes: A Study of Survival and Oxidative Stress Metabolism. Physiol. Plant. 2011, 142, 326-338. [CrossRef]

44. Schopfer, P.; Plachy, C.; Frahry, G. Release of Reactive Oxygen Intermediates (Superoxide Radicals, Hydrogen Peroxide, and Hydroxyl Radicals) and Peroxidase in Germinating Radish Seeds Controlled by Light, Gibberellin, and Abscisic Acid. Plant Physiol. 2001, 125, 1591-1602. [CrossRef]

45. Choi, H.S.; Kim, J.W.; Cha, Y.-N.; Kim, C. A Quantitative Nitroblue Tetrazolium Assay for Determining Intracellular Superoxide Anion Production in Phagocytic Cells. J. Immunoassay Immunochem. 2006, 27, 31-44. [CrossRef]

46. Giertych, M.J.; Suszka, J. Consequences of Cutting off Distal Ends of Cotyledons of Quercus robur Acorns before Sowing. Ann. For. Sci. 2011, 68, 433-442. [CrossRef]

47. R: A Language and Environment for Statistical Computing. Available online: https://www.gbif.org/tool/81287/r-a-languageand-environment-for-statistical-computing (accessed on 30 August 2021).

48. Corrplot: Visualization of a Correlation Matrix Version 0.90 from CRAN. Available online: https://rdrr.io/cran/corrplot/ (accessed on 30 August 2021).

49. Jagadish, S.V.K.; Way, D.A.; Sharkey, T.D. Plant Heat Stress: Concepts Directing Future Research. Plant Cell Environ. 2021, 44, 1992-2005. [CrossRef]

50. Fan, Y.; Ma, C.; Huang, Z.; Abid, M.; Jiang, S.; Dai, T.; Zhang, W.; Ma, S.; Jiang, D.; Han, X. Heat Priming During Early Reproductive Stages Enhances Thermo-Tolerance to Post-Anthesis Heat Stress via Improving Photosynthesis and Plant Productivity in Winter Wheat (Triticum aestivum L.). Front. Plant Sci. 2018, 9, 805. [CrossRef] [PubMed]

51. Vierling, E. The Roles of Heat Shock Proteins in Plants. Annu. Rev. Plant Physiol. Plant Mol. Biol. 1991, 42, 579-620. [CrossRef]

52. Lin, M.; Chai, K.; Ko, S.; Kuang, L.; Lur, H.; Charng, Y. A Positive Feedback Loop between HEAT SHOCK PROTEIN101 and HEAT STRESS-ASSOCIATED 32-KD PROTEIN Modulates Long-Term Acquired Thermotolerance Illustrating Diverse Heat Stress Responses in Rice Varieties. Plant Physiol. 2014, 164, 2045-2053. [CrossRef] [PubMed]

53. Charng, Y.-Y.; Liu, H.-C.; Liu, N.-Y.; Chi, W.-T.; Wang, C.-N.; Chang, S.-H.; Wang, T.-T. A Heat-Inducible Transcription Factor, HsfA2, Is Required for Extension of Acquired Thermotolerance in Arabidopsis. Plant Physiol. 2007, 143, 251-262. [CrossRef]

54. Kim, K.-H.; Alam, I.; Kim, Y.-G.; Sharmin, S.A.; Lee, K.-W.; Lee, S.-H.; Lee, B.-H. Overexpression of a Chloroplast-Localized Small Heat Shock Protein OsHSP26 Confers Enhanced Tolerance against Oxidative and Heat Stresses in Tall Fescue. Biotechnol. Lett. 2012, 34, 371-377. [CrossRef]

55. Suzuki, N.; Katano, K. Coordination Between ROS Regulatory Systems and Other Pathways Under Heat Stress and Pathogen Attack. Front. Plant Sci. 2018, 9, 490. [CrossRef]

56. Wang, L.; Ma, K.-B.; Lu, Z.-G.; Ren, S.-X.; Jiang, H.-R.; Cui, J.-W.; Chen, G.; Teng, N.-J.; Lam, H.-M.; Jin, B. Differential Physiological, Transcriptomic and Metabolomic Responses of Arabidopsis Leaves under Prolonged Warming and Heat Shock. BMC Plant Biol. 2020, 20, 86. [CrossRef]

57. Mittler, R. ROS Are Good. Trends Plant Sci. 2017, 22, 11-19. [CrossRef]

58. Robert, U.; Etuk, S.; Ubong, A.; Umoren, G.; Agbasi, O.; Abdulrazzaq, Z. Thermal and Mechanical Properties of Fabricated Plaster of Paris Filled with Groundnut Seed Coat and Waste Newspaper Materials for Structural Application. Epitoanyag-J. Silic. Based Compos. Mater. 2020, 72, 72-78. [CrossRef]

59. Yi, X.; Wang, Z.; Liu, C.; Liu, G.; Zhang, M. Acorn Cotyledons Are Larger than Their Seedlings' Need: Evidence from Artificial Cutting Experiments. Sci. Rep. 2015, 5, 8112. [CrossRef]

60. Finch-Savage, W.E. Embryo Water Status and Survival in the Recalcitrant Species Quercus robur L.: Evidence for a Critical Moisture Content. J. Exp. Bot. 1992, 43, 663-669. [CrossRef]

61. Finch-Savage, W.E. Seed Development in the Recalcitrant Species Quercus robur L.: Germinability and Desiccation Tolerance. Seed Sci. Res. 1992, 2, 17-22. [CrossRef]

62. Rajjou, L.; Lovigny, Y.; Groot, S.P.C.; Belghazi, M.; Job, C.; Job, D. Proteome-Wide Characterization of Seed Aging in Arabidopsis: A Comparison between Artificial and Natural Aging Protocols. Plant Physiol. 2008, 148, 620-641. [CrossRef] [PubMed]

63. Kendall, E.; Mckersie, B. Free Radical and Freezing Injury to Cell Membranes of Winter Wheat. Physiol. Plant. 1989, 76, 86-94. [CrossRef]

64. Devireddy, A.R.; Tschaplinski, T.J.; Tuskan, G.A.; Muchero, W.; Chen, J.-G. Role of Reactive Oxygen Species and Hormones in Plant Responses to Temperature Changes. Int. J. Mol. Sci. 2021, 22, 8843. [CrossRef]

65. Richards, S.L.; Wilkins, K.A.; Swarbreck, S.M.; Anderson, A.A.; Habib, N.; Smith, A.G.; McAinsh, M.; Davies, J.M. The Hydroxyl Radical in Plants: From Seed to Seed. J. Exp. Bot. 2015, 66, 37-46. [CrossRef] 
66. Laohavisit, A.; Richards, S.L.; Shabala, L.; Chen, C.; Colaço, R.D.D.R.; Swarbreck, S.M.; Shaw, E.; Dark, A.; Shabala, S.; Shang, Z.; et al. Salinity-Induced Calcium Signaling and Root Adaptation in Arabidopsis Require the Calcium Regulatory Protein Annexin1. Plant Physiol. 2013, 163, 253-262. [CrossRef]

67. Okuda, T.; Matsuda, Y.; Sagisaka, S. Formation of Hydroxyl Radicals in the Stems of Winter Wheat Treated with Freezing Temperature. Biosci. Biotechnol. Biochem. 1994, 58, 1189-1190. [CrossRef]

68. Chmielarz, P.; Suszka, J. Wawrzyniak MK Desiccation Sensitivity and Frost Resistance of Oak (Quercus robur L.) Seeds. Ann. For. Sci. 2021. (under review).

69. Baek, K.-H. Production of Reactive Oxygen Species by Freezing Stress and the Protective Roles of Antioxidant Enzymes in Plants. J. Agric. Chem. Environ. 2012, 01, 34-40. [CrossRef]

70. Berwal, M.K.; Ram, C. Superoxide Dismutase: A Stable Biochemical Marker for Abiotic Stress Tolerance in Higher Plants. In Abiotic and Biotic Stress in Plants; De Oliveira, A., Ed.; IntechOpen: London, UK, 2018; ISBN 978-1-78923-812-9.

71. Leggatt, C.W. Catalase Activity as a Measure of Seed Viability. Master's Thesis, University of Alberta, 1928.

72. Mhamdi, A.; Queval, G.; Chaouch, S.; Vanderauwera, S.; Van Breusegem, F.; Noctor, G. Catalase Function in Plants: A Focus on Arabidopsis Mutants as Stress-Mimic Models. J. Exp. Bot. 2010, 61, 4197-4220. [CrossRef]

73. Palma, J.M.; Gupta, D.K.; Corpas, F.J. Hydrogen Peroxide and Nitric Oxide Generation in Plant Cells: Overview and Queries. In Nitric Oxide and Hydrogen Peroxide Signaling in Higher Plants; Gupta, D.K., Palma, J.M., Corpas, F.J., Eds.; Springer International Publishing: Cham, Switzerland, 2019; pp. 1-16, ISBN 978-3-030-11129-8.

74. Palma, J.M.; Mateos, R.M.; López-Jaramillo, J.; Rodríguez-Ruiz, M.; González-Gordo, S.; Lechuga-Sancho, A.M.; Corpas, F.J. Plant Catalases as $\mathrm{NO}$ and $\mathrm{H}_{2} \mathrm{~S}$ Targets. Redox Biol. 2020, 34, 101525. [CrossRef] [PubMed]

75. Bischoff, A.; Steinger, T.; Müller-Schärer, H. The Importance of Plant Provenance and Genotypic Diversity of Seed Material Used for Ecological Restoration. Restor. Ecol. 2010, 18, 338-348. [CrossRef]

76. Bharuth, V.; Naidoo, C.; Pammenter, N.W.; Lamb, J.M.; Moodley, T. Responses to Chilling of Recalcitrant Seeds of Ekebergia Capensis from Different Provenances. S. Afr. J. Bot. 2020, 130, 8-24. [CrossRef]

77. Atkinson, R.J.; Thomas, E.; Roscioli, F.; Cornelius, J.P.; Zamora-Cristales, R.; Franco Chuaire, M.; Alcázar, C.; Mesén, F.; Lopez, H.; Ipinza, R.; et al. Seeding Resilient Restoration: An Indicator System for the Analysis of Tree Seed Systems. Diversity 2021, $13,367$. [CrossRef]

78. Buras, A.; Sass-Klaassen, U.; Verbeek, I.; Copini, P. Provenance Selection and Site Conditions Determine Growth Performance of Pedunculate Oak. Dendrochronologia 2020, 61, 125705. [CrossRef]

79. Arend, M.; Kuster, T.; Günthardt-Goerg, M.S.; Dobbertin, M. Provenance-Specific Growth Responses to Drought and Air Warming in Three European Oak Species (Quercus robur, Q. petraea and Q. pubescens). Tree Physiol. 2011, 31, 287-297. [CrossRef]

80. Matthews, S.; Powell, A.A.; Vigour, S. Electrical Conductivity Vigour Test: Physiological Basis and Use. Seed Test. Int. 2006, 131, 32-35.

81. Gupta, R.; Deswal, R. Antifreeze Proteins Enable Plants to Survive in Freezing Conditions. J. Biosci. 2014, 39, 931-944. [CrossRef] 